\title{
Gross alpha and gross beta activities in selected marine species in Vietnam
}

\author{
Hao Duong Van ${ }^{1} \cdot$ Huy Le Luong ${ }^{2} \cdot$ Chau Nguyen Dinh ${ }^{2}$ • Duong Nguyen Thanh ${ }^{3} \cdot$ Miklós Hegedüs $^{4} \cdot$ Anita Csordás $^{4}$. \\ Tibor Kovács ${ }^{4}$
}

Received: 17 April 2020 / Accepted: 23 June 2020 / Published online: 1 July 2020

(C) The Author(s) 2020

\begin{abstract}
The measured gross alpha and gross beta activities in the edible muscle tissues of eleven selected marine species along the coast of North Vietnam varied from $10.2 \pm 1.5$ to $73.2 \pm 8.1 \mathrm{~Bq} / \mathrm{kg}$ (wwt) and from $10.6 \pm 0.4$ to $68.8 \pm 2.8 \mathrm{~Bq} / \mathrm{kg}$ (wwt), respectively. The lowest gross alpha activity was recorded for bigfin reef squid (Sepioteuthis lessoniana) as a result of its carnivorous diet, and the highest alpha activity was noted for blood cockle (Anadara granosa) as a result of its omnivorous diet. However, the gross beta activities in both carnivorous and omnivorous species were similar. The highest and lowest gross beta activities were observed for narrow-barred Spanish mackerel (Scomberomorus commerson) and for bigfin reef squid and squid (Teuthida), respectively. All three aforementioned species have carnivorous diets. The calculated annual committed effective dose resulting from the consumption of $25 \mathrm{~kg}$ of muscle tissue per year varied from 192 to $1375 \mu \mathrm{S}$ with an average of $689 \mu \mathrm{S}$.
\end{abstract}

Keywords Gross alpha and beta activities $\cdot$ Ingestion dose $\cdot$ Seafood $\cdot$ Radionuclides $\cdot$ Marine pollution

\section{Introduction}

Radionuclides of various origins are present in seawater, and some elements behave conservatively and remain in their soluble form in water, whereas others are insoluble, or adhere to particles, and sooner or later are transferred to marine sediments (IAEA 2005). In the marine environment, ${ }^{238} \mathrm{U},{ }^{210} \mathrm{~Pb}$, ${ }^{210} \mathrm{Po}$, and ${ }^{40} \mathrm{~K}$ are the most abundant natural radionuclides and are ultimately derived from the weathering of rocks or fallout from the atmosphere in the form of rain and are transported by river discharge (Cochran 1982; Chen et al. 2016; Filizok and Uğur Görgün 2019; Mohan et al. 2019;

Responsible Editor: Georg Steinhauser

Tibor Kovács

kt@almos.uni-pannon.hu

1 Institute of Research and Development, Duy Tan University, Da Nang 550000, Vietnam

2 AGH University of Science and Technology (AGH UST), Krakow, Poland

3 Hanoi University of Mining and Geology (HUMG), Hanoi 100000, Vietnam

4 Institute of Radiochemistry and Radioecology, University of Pannonia, Veszprém, Hungary
Peng et al. 2019). Three main sources of isotopes of artificial radionuclides exist, namely, nuclear weapons testing, the nuclear accidents at Chernobyl as well as Fukushima, and waterborne discharges from nuclear reprocessing plants (Beresford et al. 2020; Hirose et al. 1999; Kaizer et al. 2017; Kato et al. 2018; Kawamura et al. 2017; McKenzie and Dulai 2017; Nishikiori and Suzuki 2017; Ogata 2013; Ramzaev et al. 2008; Savino et al. 2017; Vlasova et al. 2015). Other sources contribute less contamination, e.g., ocean dumping of nuclear waste, routine discharges from nuclear power plants, sunken nuclear submarines, lost satellites as well as nuclear weapons, and the use of radioisotopes in medicine, industry, and science (IAEA 2005).

Several research projects concerning radiation activity, namely, that of ${ }^{40} \mathrm{~K},{ }^{238} \mathrm{U},{ }^{232} \mathrm{Th},{ }^{137} \mathrm{Cs},{ }^{134} \mathrm{Cs},{ }^{210} \mathrm{Po}$, and ${ }^{210} \mathrm{~Pb}$ concentrations in marine organisms and fish, are ongoing (Ababneh et al. 2018; Alam et al. 1995; Szefer et al. 1990). Specifically, Nandhakumari et al. (2014) studied the radioactivity content in sediment, water, and fish collected from the Rajakkamangalam Estuary of Kanyakumari District in the state of Tamil Nadu, India. Mean gross alpha and beta activity concentrations of $57.38 \mathrm{~Bq} / \mathrm{kg}$ and $123.67 \mathrm{~Bq} / \mathrm{kg}$ were measured, respectively (NandhaKumari et al. 2014). Zorer and Öter (2015) reported the results of their evaluation concerning gross radioactivity in foodstuffs. In their study, food items 
were divided into eight groups, and the levels of gross alpha and gross beta radioactivity varied tremendously from 70 to $10,885 \mathrm{~Bq} / \mathrm{kg}$ and from 132 to $48,285 \mathrm{~Bq} / \mathrm{kg}$ on dry mass basis, respectively. The average gross alpha and gross beta activities of fresh fish were reported to be $625 \mathrm{~Bq} / \mathrm{kg}$ and $2863 \mathrm{~Bq} / \mathrm{kg}$, respectively, while for salted fish, the average gross alpha activity was not detected, but the average gross beta activity was $1554 \mathrm{~Bq} / \mathrm{kg}$ (Zorer and Öter 2015). It must be noted that gross alpha and beta measurements have some limitations; depending on the measurement method, they cannot be easily compared, and certain radionuclides might not be measured (Jobbágy et al. 2014). In Vietnam, radioactivity in food has rarely been investigated (Van et al. 2018), and no baselines for radioactivity levels are available. Therefore, the objectives of this study are to (i) determine gross alpha and gross beta activities in different selected marine species in the East Sea of Vietnam and (ii) estimate the annual committed effective dose following the consumption of marine species.

\section{Experimental study}

\section{Sampling and sample preparation}

The eleven representative samples of seafood collected represent the most commonly consumed marine species in Vietnam, namely, Lyrate hard clam (Meretrix lyrata), silver pomfret (Pampus argenteus), narrow-barred Spanish mackerel (Scomberomorus commerson), shortfin scad (Decapterus sp.), Indian mackerel (Rastrelliger kanagurta), blood cockle/ granular ark clam (Anadara granosa), giant tiger prawn (Penaeus monodon), tuna (Thunnini), squid (Teuthida), bigfin reef squid (Sepioteuthis lessoniana), and groupers (Epinephelinae). The local names, English names, and scientific names of each sample collected in the study according to Froese and Pauly (2019), Palomares and Pauly (2019) and also their feeding habits are listed in Table 1. The trophic levels presented in Table 1 were taken from the databases FishBase and SealifeBase and Pinnegar et al. (2003).

In the laboratory, the studied samples were washed with distilled water three times. The samples were separated into edible muscle tissues (which were used to assess the gross alpha and gross beta activities humans are exposed to following their consumption) and all other components (bones and hard parts). The edible muscle tissues were weighed and ovendried at $90{ }^{\circ} \mathrm{C}$ to a constant weight and then powdered, homogenized, and reweighed to determine the dry mass to wet mass ratio. Next, the powdered samples were wet-digested using a mixed solution of $\mathrm{HNO}_{3}$ and $\mathrm{HCl}$ (1:3) followed by the addition of $\mathrm{H}_{2} \mathrm{O}_{2}$ until the digestion was complete. Following digestion, the samples were evaporated, and the precipitates that remained were used in the next step. A certain amount of residue from each sample was used for each measurement and spread onto the surface of the measuring trays. To ensure accurate counting and measurement stability, the density of gross $\alpha$ and gross $\beta$ activities was $0.05 \mathrm{mg} / \mathrm{mm}^{2}$ and $0.10 \mathrm{mg} / \mathrm{mm}^{2}$, respectively. The size of the trays in this study was $25 \mathrm{~mm}$, so the calculated masses of residues from each sample used to measure gross alpha and gross beta activities were controlled at $98 \mathrm{mg}$ and $196 \mathrm{mg} \pm 5 \%$, respectively. To subtract the background radiation, a background radiation sample was also prepared; moreover, for the purpose of calibration, standard samples were measured. In order to maintain the counting efficiency of the instrument and avoid self-absorption by the samples from influencing the measurement results which are affected by the density and mass thickness of the samples, the masses of the samples of residues were calculated according to the following formula (Gorur

Table 1 The marine organisms in this study and their feeding habits

\begin{tabular}{|c|c|c|c|c|}
\hline Local name & English name & Scientific name & Feeding habits & Trophic level \\
\hline Cá Song & Groupers & Epinephelus sp. & $\begin{array}{l}\text { Carnivores: crustaceans, octopodes, young sea } \\
\text { turtles, other fish }\end{array}$ & $(3.7)$ \\
\hline Cá Ngừ & Tuna & Thunnus sp. & Carnivores: fishes and invertebrates & $(4.5)$ \\
\hline Cá Nục & Shortfin scad & Decapterus sp. & Carnivores: planktonic crustaceans and fishes & $(3.4)$ \\
\hline Mực Ống & Squid & Loligo sp. & Carnivores: other crustaceans and fish & (3.8) \\
\hline Mực Lá & Bigfin reef squid & Sepioteuthis lessoniana & Carnivores: other crustaceans and fish & $(4.0)$ \\
\hline Cá Thu & Narrow-barred Spanish mackerel & Scomberomorus commerson & Carnivores: small fishes & $(4.5)$ \\
\hline Cá chim trắng & Silver pomfret & Pampus argenteus & Carnivores: Crustacea, Bacillariophyta, Mollusca & $(3.3)$ \\
\hline Cá Bạc Má & Indian mackerel & Rastrelliger kanagurta & Omnivores: macro planktons, crustacean, mollusks & $(3.2)$ \\
\hline Con Ngao & Lyrate hard clam & Meretrix lyrata & Omnivores: organic particles, planktons & $(2.2)$ \\
\hline Sò huyết & Granular ark/blood cockle & Tegillarca granosa & Omnivores: planktons, organic particles & $(2.0)$ \\
\hline Tôm sú & Giant tiger prawn & Penaeus monodon & $\begin{array}{l}\text { Omnivores: phytoplankton, zooplankton, crustaceans, } \\
\text { detritus, mollusks, fish parts, and mud }\end{array}$ & $(3.4)$ \\
\hline
\end{tabular}


and Camgoz 2014):

$\mathrm{M}=\mathrm{T}_{\mathrm{a}} * \mathrm{~A}$

where $M$ denotes the mass of the sample of residue $(\mathrm{mg}), T_{\mathrm{a}}$ represents the mass thickness of the sample of residue $(\mathrm{mg} /$ $\mathrm{mm}^{2}$ ), and $A$ stands for the effective measurement area of the sample of residue $\left(\mathrm{mm}^{2}\right)$.

\section{Experimental instrument}

The prepared samples were counted to determine the gross alpha and gross beta activities using a Canberra LB4100 low-background gas proportional counter (Canberra Company, USA) calibrated with ${ }^{241} \mathrm{Am}$ and ${ }^{90} \mathrm{Sr}$ standard surface sources. Low background count rates of $0.10 \mathrm{cpm}$ and $<0.93 \mathrm{cpm}$ for gross alpha and gross beta activities were used, respectively, using a gas proportional counter with a gas composition of $10 \%$ methane $+90 \%$ argon. All the studied background and standard samples were measured over $86,400 \mathrm{~s}$, and alpha and beta efficiencies of $20-25 \%$ and 30-40\% were determined, respectively.

The minimum detectable activity of the instrument was determined in accordance with research conducted by Janković et al. (2012) and Turgay et al. (2015), which are based on the article of Currie (1968) as follows:

$\operatorname{MDA}(B q / l)=L_{d} / V^{*} T^{*} \varepsilon^{*} 60$

where $L_{\mathrm{d}}=2.71+4.65 \sqrt{ }(\mathrm{Bc} * T), V$ denotes the volume of the measured sample (liter), $T$ represents the measurement time (min), $\varepsilon$ stands for the detection efficiency, and $\mathrm{Bc}$ is the background count rate (cpm). The minimum detectable activity of the measurement system was calculated to be $1.6 \mathrm{mBq} \mathrm{L}^{-1}$ and $1.4 \mathrm{mBq} \mathrm{L}^{-1}$ for gross alpha and gross beta activities, respectively.

\section{Results and discussion}

The gross alpha and gross beta activities in selected marine organisms are presented in Table 2 . The results show that the dry mass to wet mass ratios of the marine organisms ranged from 0.12 to 0.30 with an average of $0.23 \pm 0.06$. The mean gross alpha and gross beta activities varied over a wide range from 10.2 and $10.6 \mathrm{~Bq} / \mathrm{kg}$ (wwt) to 73.2 and $68.8 \mathrm{~Bq} / \mathrm{kg}$ (wwt) for alpha and beta, respectively.

The mean gross alpha and gross beta activities in the 11 marine species investigated were $35.6 \mathrm{~Bq} / \mathrm{kg}$ (wwt) and 43.7 Bq/kg (wwt), respectively. The measured gross beta activity in the marine creatures exceeded $10 \mathrm{~Bq} / \mathrm{kg}$. The gross beta activity was greater than the gross alpha activity, which was also observed in fish samples from Lake Van, Turkey (Erenturk et al. 2014), because among the naturally occurring gamma-emitting radionuclides, the concentrations of radioactive potassium $\left({ }^{40} \mathrm{~K}\right)$ was the highest (Carvalho et al. 2011).

The activity is much lower in bigfin reef squid (Sepioteuthis lessoniana) with gross alpha and gross beta activities of $10.2 \mathrm{~Bq} / \mathrm{kg}$ (wwt) and $10.6 \mathrm{~Bq} / \mathrm{kg}$ (wwt), respectively, which is related to its carnivorous feeding type. The diet of bigfin reef squid consists of crustaceans and fish. The gross alpha activity of species that belong to the carnivorous feeding type ranges from $10.2 \pm 1.5$ to $61.0 \pm 6.8 \mathrm{~Bq} / \mathrm{kg}$ (wwt) (groupers, tuna, shortfin scad, squid, bigfin reef squid, narrow-barred Spanish mackerel, silver pomfret) while that of species belonging to the omnivorous feeding type ranges from $29.7 \pm 2.4$ to $73.2 \pm 8.1 \mathrm{~Bq} / \mathrm{kg}$ (wwt) (India mackerel, Lyrate hard lam, blood cockle, giant tiger prawn). The variation in the gross alpha activity of various species of marine food collected from the same coastal region could be attributed to the metabolism, feeding type, and size of the species. Some studies showed that lower activities of radionuclides detected in carnivorous marine fish could be related to their slower rate of metabolism (Mat Çatal et al. 2012; Ababneh et al. 2018). The highest gross alpha activity of $73.2 \pm 8.1 \mathrm{~Bq} /$ $\mathrm{kg}$ (wwt) was measured in blood cockle (Anadara granosa), an omnivorous bottom feeder whose diet consists of plankton and organic particles. Given the feeding type of blood cockle, radionuclides probably have a high degree of association with organic matter. Its environment, plankton, and bottom-feeding habits were suggested to lead to the accumulation of and significantly contribute to the relatively high radionuclide activity (Ababneh et al. 2018; Aközcan 2013; Chen et al. 2016; Raja and Shahul Hameed 2010; Štrok and Smodiš 2011). The relatively high gross alpha activities of the omnivorous species Lyrate hard clam and giant tiger prawn (Penaeus monodon) are $58.5 \pm 5.3 \mathrm{~Bq} / \mathrm{kg}$ (wwt) and $43.7 \pm 5.5 \mathrm{~Bq} / \mathrm{kg}$ (wwt), respectively. Bivalve mollusks, e.g., blood cockle and Lyrate hard clam, are capable of accumulating contaminants in biological systems, so they are used as indicators of pollution not only in terms of radionuclides but also heavy metals as well as pesticides (Forester 1980) and accumulate much more radiation activity than other marine organisms (Musthafa and Krishnamoorthy 2011). However, the gross alpha activity in tuna (Thunnini), a carnivorous species, was close to the highest value $73.2 \pm 8.1 \mathrm{~Bq} / \mathrm{kg}$ (wwt). It should be noted that gross alpha activity not only depends on feeding habits, the rate of metabolism, and the environment but also on the size of the species, its age, and other parameters, e.g., the depth and temperature of the water. The tuna in this study was the biggest species.

The gross beta activity of species that belong to the carnivorous feeding type ranges from $10.6 \pm 0.4$ to $68.8 \pm 2.8 \mathrm{~Bq} / \mathrm{kg}$ (wwt) while that of those belonging to the omnivorous feeding type ranges from $42.1 \pm 2.4$ to $62.4 \pm 3.0 \mathrm{~Bq} / \mathrm{kg}$ (wwt). The gross beta activity of species that belong to carnivorous and omnivorous feeding types is insignificantly different. 
Table 2 Dry mass to wet mass ratio and gross alpha and gross beta activities in selected marine organisms

\begin{tabular}{llll}
\hline Scientific name $(n=5)$ & Dry/wet ratio & Gross alpha $(\mathrm{Bq} / \mathrm{kg} w w t)$ & Gross beta $(\mathrm{Bq} / \mathrm{kg} w w t)$ \\
\hline Epinephelinae & 0.30 & $21.6 \pm 1.7$ & $51.1 \pm 2.2$ \\
Thunnini & 0.30 & $61.0 \pm 6.8$ & $65.5 \pm 3.4$ \\
Decapterus scombrinus & 0.25 & $24.2 \pm 2.0$ & $38.3 \pm 2.0$ \\
Teuthida & 0.14 & $43.0 \pm 4.8$ & $19.1 \pm 0.8$ \\
Sepioteuthis lessoniana & 0.12 & $10.2 \pm 1.5$ & $10.6 \pm 0.4$ \\
Scomberomorus & 0.25 & $13.3 \pm 0.7$ & $68.8 \pm 2.8$ \\
Pampus argenteus & 0.25 & $23.4 \pm 1.8$ & $39.0 \pm 2.0$ \\
Rastrelliger kanagurta & 0.27 & $29.7 \pm 2.4$ & $62.4 \pm 3.0$ \\
Veneridae & 0.27 & $58.5 \pm 5.3$ & $47.8 \pm 1.8$ \\
Anadara granosa & 0.17 & $73.2 \pm 8.1$ & $42.1 \pm 2.4$ \\
Penaeus monodon & 0.21 & $43.7 \pm 5.5$ & $36.4 \pm 1.8$ \\
Minimum & 0.12 & 10.2 & 10.6 \\
Maximum & 0.3 & 73.2 & 68.8 \\
Average value & 0.23 & 35.6 & 43.7 \\
\hline
\end{tabular}

However, the lowest and highest gross beta activities are observed in species that belong to the carnivorous feeding type with $10.6 \pm 0.4 \mathrm{~Bq} / \mathrm{kg}$ (wwt) for bigfin reef squid (Sepioteuthis lessoniana) as well as $19.1 \pm 0.8 \mathrm{~Bq} / \mathrm{kg}$ (wwt) for squid (Teuthida) and $68.8 \pm 2.8 \mathrm{~Bq} / \mathrm{kg}$ (wwt) for narrow-barred Spanish mackerel (Scomberomorus commerson). In general, the highest beta activity was measured in two carnivorous species, namely, $68.8 \pm 2.8 \mathrm{~Bq} / \mathrm{kg}$ (wwt) for narrow-barred Spanish mackerel (Scomberomorus commerson) and $65.5 \pm$ $3.4 \mathrm{~Bq} / \mathrm{kg}$ (wwt) for tuna (Thunnini). These species were regarded as large fish. In addition, these fishes are found at the top of the aquatic food chain (Fig. 1), are important sources of food for humans (Aközcan and Uğur 2013), and tend to accumulate a great amount of toxicity and radiation (Milenkovic et al. 2019).

The annual effective dose received by an adult due to consumption of seafood was calculated using the following formula:

$\mathrm{DR}_{\mathrm{r}}=\mathrm{G}_{\mathrm{r}} \times \mathrm{CI}_{\mathrm{r}} \times \mathrm{DC}_{\mathrm{r}}$

where $D R_{r}$ denotes the annual effective dose ( $\left.\mu \mathrm{Sv} / \mathrm{y}\right), G_{r}$ represents the gross $\alpha$ or gross $\beta$ activity $(\mathrm{mBq} / \mathrm{l}), C I_{r}$ stands for
Fig. 1 Food chain in a marine ecosystem

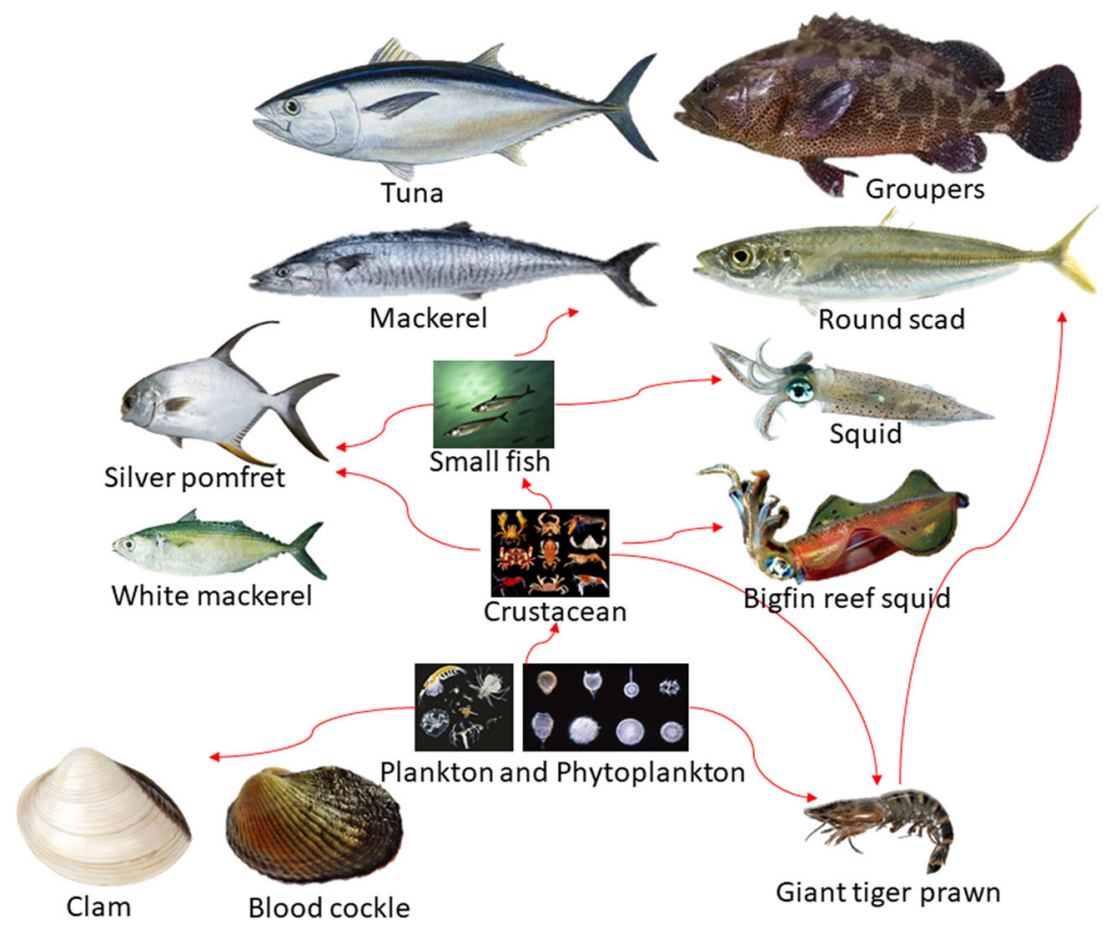


Table 3 Annual effective dose $(\mu \mathrm{Sv} / \mathrm{y})$ of radiation source in seafood for adults

\begin{tabular}{|c|c|c|c|c|c|c|c|}
\hline English name & $\mathrm{U}-238^{*}$ & $\mathrm{U}-235^{*}$ & U-234* & Ra-226* & Po- $210 *$ & $\mathrm{~Pb}-210^{\#}$ & Total \\
\hline Groupers & $0.31 \pm 0.02$ & $0.01 \pm 0.00$ & $0.34 \pm 0.03$ & $20.4 \pm 1.6$ & $383 \pm 30$ & $0.53 \pm 0.02$ & $405 \pm 32$ \\
\hline Tuna & $0.87 \pm 0.10$ & $0.04 \pm 0.00$ & $0.95 \pm 0.11$ & $57.6 \pm 6.4$ & $1082 \pm 121$ & $0.68 \pm 0.04$ & $1142 \pm 127$ \\
\hline Shortfin scad & $0.35 \pm 0.03$ & $0.01 \pm 0.00$ & $0.38 \pm 0.03$ & $22.8 \pm 1.9$ & $429 \pm 35$ & $0.40 \pm 0.02$ & $453 \pm 37$ \\
\hline Squid & $0.61 \pm 0.07$ & $0.03 \pm 0.00$ & $0.67 \pm 0.07$ & $40.6 \pm 4.5$ & $763 \pm 85$ & $0.20 \pm 0.01$ & $805 \pm 90$ \\
\hline Bigfin reef squid & $0.15 \pm 0.02$ & $0.01 \pm 0.00$ & $0.16 \pm 0.02$ & $9.6 \pm 1.4$ & $181 \pm 27$ & $0.11 \pm 0.00$ & $191 \pm 28$ \\
\hline Narrow-barred Spanish mackerel & $0.19 \pm 0.01$ & $0.01 \pm 0.00$ & $0.21 \pm 0.01$ & $12.6 \pm 0.7$ & $236 \pm 12$ & $0.72 \pm 0.03$ & $250 \pm 13$ \\
\hline Silver pomfret & $0.33 \pm 0.03$ & $0.01 \pm 0.00$ & $0.37 \pm 0.03$ & $22.1 \pm 1.7$ & $415 \pm 32$ & $0.41 \pm 0.02$ & $438 \pm 34$ \\
\hline Indian mackerel & $0.42 \pm 0.03$ & $0.02 \pm 0.00$ & $0.46 \pm 0.04$ & $28.0 \pm 2.3$ & $527 \pm 43$ & $0.65 \pm 0.03$ & $557 \pm 45$ \\
\hline Lyrate hard clam & $0.84 \pm 0.08$ & $0.04 \pm 0.00$ & $0.92 \pm 0.08$ & $55.2 \pm 5.0$ & $1037 \pm 94$ & $0.50 \pm 0.02$ & $1095 \pm 99$ \\
\hline Granular ark /blood cockle & $1.05 \pm 0.12$ & $0.04 \pm 0.00$ & $1.15 \pm 0.13$ & $69.1 \pm 7.6$ & $1298 \pm 144$ & $0.44 \pm 0.03$ & $1370 \pm 152$ \\
\hline Giant tiger prawn & $0.62 \pm 0.08$ & $0.03 \pm 0.00$ & $0.68 \pm 0.09$ & $41.3 \pm 5.2$ & $775 \pm 98$ & $0.38 \pm 0.02$ & $818 \pm 103$ \\
\hline Average & 0.52 & 0.02 & 0.57 & 34.5 & 647 & 0.46 & 684 \\
\hline
\end{tabular}

*The annual effective dose values and uncertainties in this table are estimations based on gross alpha and gross beta values, not measured individual activity concentrations

Fig. 2 aThe relationship between the total annual effective dose and gross alpha activity. b The relationship between the total annual effective dose and gross beta activity
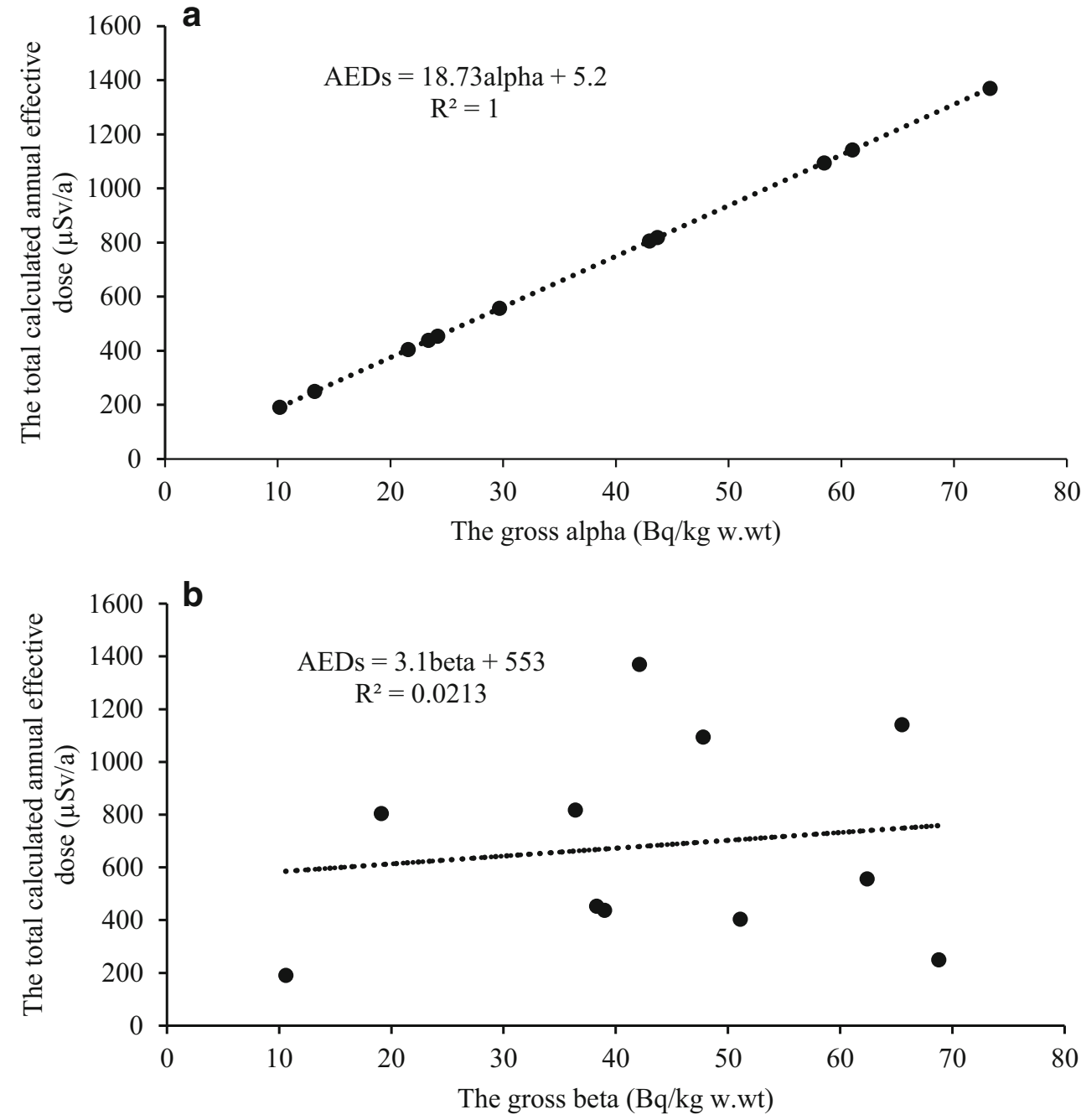

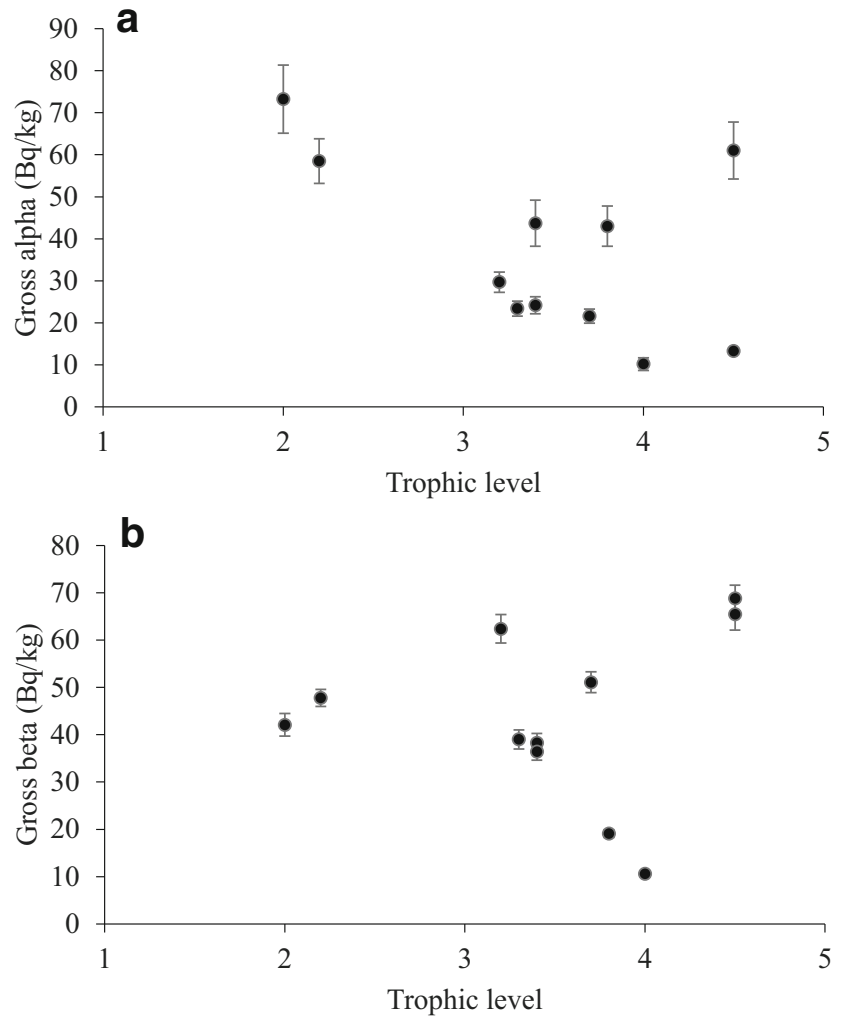

Fig. 3 a The relationship between trophic level and gross alpha activity. b The relationship between trophic level and gross beta activity

the amount of seafood consumed in 1 year $(\mathrm{kg})$, and $D C_{r}$ is the dose conversion coefficient ( $\mathrm{Sv} / \mathrm{Bq}$ ). According to the National Institute of Nutrition in Vietnam, the consumption of seafood in Vietnam is increasing year by year with an average of $18.8 \mathrm{~kg} /$ year eaten by adults (Ministry of Health 2010). Following the annual dose conversion factors issued by the World Health Organization (WHO 2017), the annual dose conversion factors used to calculate the annual effective dose of different sources of radionuclides were as follows: ${ }^{238} \mathrm{U}=$ $4.5 \times 10^{-8} \mathrm{~Sv} / \mathrm{Bq},{ }^{235} \mathrm{U}=4.7 \times 10^{-8} \mathrm{~Sv} / \mathrm{Bq},{ }^{234} \mathrm{U}=4.9 \times$ $10^{-8} \mathrm{~Sv} / \mathrm{Bq},{ }^{226} \mathrm{Ra}=2.8 \times 10^{-7} \mathrm{~Sv} / \mathrm{Bq},{ }^{210} \mathrm{Po}=1.2 \times 10^{-6} \mathrm{~Sv} /$ $\mathrm{Bq},{ }^{210} \mathrm{~Pb}=6.9 \times 10^{-7} \mathrm{~Sv} / \mathrm{Bq}$ (WHO 2017), and ${ }^{40} \mathrm{~K}=6.2 \times$ $10^{-9} \mathrm{~Sv} / \mathrm{Bq}$ (ICRP 2012). Based on research by Carvalho et al. (2011) concerning deep sea fish and other organisms, the authors calculated the percentages of ${ }^{238} \mathrm{U},{ }^{235} \mathrm{U},{ }^{234} \mathrm{U},{ }^{40} \mathrm{~K}$, ${ }^{210} \mathrm{~Pb},{ }^{210} \mathrm{Po}$, and ${ }^{226} \mathrm{Ra}$ in the gross alpha and gross beta activities. The calculated results showed that the percentages of ${ }^{238} \mathrm{U},{ }^{235} \mathrm{U},{ }^{234} \mathrm{U},{ }^{226} \mathrm{Ra}$, and ${ }^{210}$ Po were 1.7, 0.1, 1.7, 17.9, and $78.6 \%$ in terms of gross alpha activity, respectively, and for ${ }^{210} \mathrm{~Pb}$ and ${ }^{40} \mathrm{~K}, 0.1$ and $99.9 \%$ in terms of gross beta activity, respectively. Some artificial radionuclides, e.g., ${ }^{134} \mathrm{Cs}$ and ${ }^{137} \mathrm{Cs}$, only emit gamma radiation; moreover, the activities of ${ }^{239} \mathrm{Pu},{ }^{240} \mathrm{Pu},{ }^{241} \mathrm{Pu},{ }^{90} \mathrm{Sr}$, and ${ }^{241} \mathrm{Am}$ are very low when compared with natural alpha and beta radiation. Therefore, when using Formula 3 to calculate the annual effective dose, those isotopes can be neglected (Table 3).
It must be noted that the presented total annual effective doses are estimates and the isotopes were not measured separately. ${ }^{210} \mathrm{Po}$ contributes the largest proportion of activity to the average annual effective dose calculated due to its digestion in seafood by adults, contributing from 181 to $1298 \mu \mathrm{S} / \mathrm{y}$ (647 $\mu \mathrm{S} / \mathrm{y}$ on average), while ${ }^{235} \mathrm{U}$ contributes the smallest proportion of activity which ranges from 0.01 to $0.04 \mu \mathrm{S} / \mathrm{y}$ $(0.02 \mu \mathrm{S} / \mathrm{y}$ on average). The order of contribution to the annual effective dose in descending order is ${ }^{210} \mathrm{Po},{ }^{226} \mathrm{Ra},{ }^{40} \mathrm{~K}$, ${ }^{234} \mathrm{U},{ }^{238} \mathrm{U},{ }^{210} \mathrm{~Pb}$, and ${ }^{235} \mathrm{U}$. The contribution to the annual effective dose for adults of the $\beta$ radiation source ${ }^{210} \mathrm{~Pb}$ is 0.46 . The gross alpha activity is significantly greater than the gross beta. There is a linear relationship between the total annual effective dose and gross alpha activity with $R^{2}=1$ (strong positive correlation with a Pearson correlation coefficient $R(11)=1, p<0.05$ ), while for the gross beta activity, $R^{2}$ $<1$ (weak positive correlation with a Pearson correlation coefficient $R(11)=0.14, p=0.681$, not significant) (Figs. 2-b). The total annual effective dose varies from 191 to $1370 \mu \mathrm{S} / \mathrm{y}$. The highest total annual effective dose belongs to an omnivorous species, blood cockle. The lowest total annual effective dose is associated with a carnivorous species, bigfin reef squid. The total average annual effective dose is $684 \mu \mathrm{S} / \mathrm{y}$ which is less than the annual effective dose limit of Vietnam (TCVN 2008).

Figure 3 and $b$ show the relationship between tropic level and gross alpha and gross beta activity concentration, respectively.

Comparing Fig. 3 and b, lower trophic levels tend to have higher gross alpha activity concentration (moderate negative correlation according to the Pearson correlation coefficient, $R(11)=-0.55, p=0.086$ ), while this is not the case for gross beta activity concentration (weak positive correlation, $R(11)=0.12, p=0.717$ ); however, neither relationship is considered significant. The relationship might be influenced by the bivalve mollusks accumulating contaminants. It should be noted that gross alpha and beta activity not only depend on feeding habits, the rate of metabolism, and the environment but also on the size of the species, its age, and other parameters, e.g., the depth and temperature of the water.

\section{Conclusion}

A study of gross alpha and gross beta activities in Vietnamese seafood is presented for the first time. The results particularly showed that the total annual effective dose is principally contributed to by gross alpha activity. Among these, the activity concentration of ${ }^{210} \mathrm{Po}$ contributed over $70 \%$ in total while that of ${ }^{235} \mathrm{U}$ was the smallest. The increase in annual effective dose is most strongly associated with ${ }^{210} \mathrm{Po}$, followed by ${ }^{226} \mathrm{Ra}$ among other radionuclides. The smallest annual effective dose belongs to the uranium isotopes and ${ }^{210} \mathrm{~Pb}$. It must be noted 
that this is based on the ratio of radionuclides in fish from Carvalho et al. (2011) and gross alpha and beta measurements, not individual radionuclide concentrations.

Of the species studied, the carnivorous bigfin reef squid (Sepioteuthis lessoniana) exhibited the lowest gross alpha activity, while the omnivorous bottom feeder, blood cockle (Anadara granosa), presented the highest gross alpha activity. With regard to gross beta activity, both the lowest and highest activities were exhibited by carnivorous species, namely, bigfin reef squid (Sepioteuthis lessoniana), squid (Teuthida), and narrow-barred Spanish mackerel (Scomberomorus commerson), respectively.

Acknowledgments Open access funding provided by University of Pannonia. The authors would like to thank the technicians in the laboratories of the Key Laboratory of Environmental and Climate Change Response, Vietnam University of Science (VNU) for supporting in conducting the experimental part of this work.

Funding information The research work is supported by the Grant of The National Foundation for Science and Technology Development (NAFOSTED), Vietnam, no. 105.05-2019.10, Hungarian National Research OTKA grant nos. K128805 and K128818, and GINOP Grant of the Hungarian Government no. 2016-0016.

Open Access This article is licensed under a Creative Commons Attribution 4.0 International License, which permits use, sharing, adaptation, distribution and reproduction in any medium or format, as long as you give appropriate credit to the original author(s) and the source, provide a link to the Creative Commons licence, and indicate if changes were made. The images or other third party material in this article are included in the article's Creative Commons licence, unless indicated otherwise in a credit line to the material. If material is not included in the article's Creative Commons licence and your intended use is not permitted by statutory regulation or exceeds the permitted use, you will need to obtain permission directly from the copyright holder. To view a copy of this licence, visit http://creativecommons.org/licenses/by/4.0/.

\section{References}

Ababneh Z, Ababneh A, Almasoud F, Alsagabi S, Alanazi Y, Aljulaymi A, Aljarrah K (2018) Assessment of the committed effective dose due to the 210Po intake from fish consumption for the Arabian Gulf population. Chemosphere 210:511-515. https://doi.org/10.1016/j. chemosphere.2018.07.045

Aközcan S (2013) Levels of ${ }^{210}$ Po in some commercial fish species consumed in the Aegean Sea coast of Turkey and the related dose assessment to the coastal population. J Environ Radioact 118:9395. https://doi.org/10.1016/j.jenvrad.2012.11.014

Aközcan S, Uğur A (2013) Activity levels of 210Po and 210Pb in some fish species of the Izmir Bay (Aegean Sea). Mar Pollut Bull 66(1-2): 234-238. https://doi.org/10.1016/j.marpolbul.2012.10.003

Alam M, Chowdhury M, Kamal M, Ghose S (1995) Radioactivity in marine fish of the Bay of Bengal. Appl Radiat Isot 46(5):363-364. https://doi.org/10.1016/0969-8043(95)00013-4

Beresford N, Barnett C, Gashchak S, Maksimenko A, Guliaichenko E, Wood M, Izquierdo M (2020) Radionuclide transfer to wildlife at a 'reference site' in the Chernobyl exclusion zone and resultant radiation exposures. Accessed 10 Apr 2020. https://doi.org/10. 1016/j.jenvrad.2018.02.007

Carvalho F, Oliveira J, Malta M (2011) Radionuclides in deep-sea fish and other organisms from the North Atlantic Ocean. ICES J Mar Sci 68(2):333-340. https://doi.org/10.1093/icesjms/fsq088

Chen J, Rennie M, Sadi B, Zhang W, St-Amant N (2016) A study on the levels of radioactivity in fish samples from the experimental lakes area in Ontario, Canada. J Environ Radioact 153:222-230. https:// doi.org/10.1016/j.jenvrad.2016.01.005

Cochran JK (1982) The oceanic chemistry of the U- and Th-series nuclides. Uranium series disequilibrium: applications to environmental problems 14(14749575)

Currie LA (1968) Limits for qualitative detection and quantitative determination: application to radiochemistry. Anal Chem 40:586-593

Erenturk S, Yusan S, Turkozu D, Camtakan Z, Olgen M, Aslani M, Aytas S, Isik M (2014) Spatial distribution and risk assessment of radioactivity and heavy metal levels of sediment, surface water and fish samples from Lake Van, Turkey. J Radioanal Nucl Chem 300(3): 919-931. https://doi.org/10.1007/s10967-014-3042-0

Filizok I, Uğur Görgün A (2019) Atmospheric depositional characteristics of ${ }^{210} \mathrm{Po},{ }^{210} \mathrm{~Pb}$ and some trace elements in İzmir, Turkey. Chemosphere 220:468-475. https://doi.org/10.1016/j. chemosphere.2018.12.150

Forester A J (1980) Monitoring the bioavailability of toxic metals in acidstressed shield lakes using pelecypod molluscs (clams, mussels) In Hemphill, D. D. (ed.) Trace substances in environmental health, XIV. University of Missouri, Columbia 142-147.

Froese R and Pauly D Editors (2019) FishBase. World Wide Web electronic publication. www.fishbase.org. Accessed 3 March 2020

Gorur F, Camgoz H (2014) Natural radioactivity in various water samples and radiation dose estimations in Bolu province, Turkey. Chemosphere 112:134-140. https://doi.org/10.1016/j. chemosphere.2014.02.074

Hirose K, Amano H, Baxter M et al (1999) Anthropogenic radionuclides in seawater in the East Sea/Japan Sea: results of the first-stage Japanese-Korean-Russian expedition. J Environ Radioact 43(1): 1-13. https://doi.org/10.1016/S0265-931X(98)00012-5

IAEA (2005) Worldwide marine radioactivity studies (WOMARS). IAEA, Vienna

ICRP (2012) ICRP publication 119: compendium of dose coefficients based on ICRP publication 60. Ann ICRP 41:1-130. https://doi. org/10.1016/j.icrp.2012.06.038

Janković M, Todorović D, Todorović N, Nikolov J (2012) Natural radionuclides in drinking waters in Serbia. Appl Radiat Isot 70(12):27032710. https://doi.org/10.1016/j.apradiso.2012.08.013

Jobbágy V, Merešová J, Wätjen U (2014) Critical remarks on gross alpha/ beta activity analysis in drinking waters: conclusions from a European interlaboratory comparison. Appl Radiat Isot 87:429 434. https://doi.org/10.1016/j.apradiso.2013.11.073

Kaizer J, Aoyama M, Kumamoto Y, Molnár M, Palcsu L, Povinec P (2017) Tritium and radiocarbon in the western North Pacific waters: post-Fukushima situation. J Environ Radioact 184-185:83-94. https://doi.org/10.1016/j.jenvrad.2018.01.015

Kato H, Onda Y, Saidin Z, Sakashita W, Hisadome K, Loffredo N (2018) Six-year monitoring study of radiocesium transfer in forest environments following the Fukushima nuclear power plant accident. J Environ Radioact 210:105817. https://doi.org/10.1016/j.jenvrad. 2018.09.015

Kawamura H, Furuno A, Kobayashi T, In T, Nakayama T, Ishikawa Y, Miyazawa Y, Usui N (2017) Oceanic dispersion of Fukushimaderived Cs-137 simulated by multiple oceanic general circulation models. J Environ Radioact 180:36-58. https://doi.org/10.1016/j. jenvrad.2017.09.020

Mat Catal E, Uğur A, Özden B, Filizok I (2012) ${ }^{210} \mathrm{Po}$ and ${ }^{210} \mathrm{~Pb}$ variations in fish species from the Aegean Sea and the contribution of 
210Po to the radiation dose. Mar Pollut Bull 64(4):801-806. https:// doi.org/10.1016/j.marpolbul.2012.01.016

McKenzie T, Dulai H (2017) Fukushima-derived radiocesium fallout in Hawaiian soils. J Environ Radioact 180:106-113. https://doi.org/10. 1016/j.jenvrad.2017.10.003

Milenkovic B, Stajic J, Stojic N, Pucarevic M, Strbac S (2019) Evaluation of heavy metals and radionuclides in fish and seafood products. Chemosphere 229:324-331. https://doi.org/10.1016/j. chemosphere.2019.04.189

Ministry of health (2010) General Nutrition Survey 2009-2010

Mohan M, D'Souza R, Nayak S, Kamath S, Shetty T, Kumara K, Mayya Y, Karunakara N (2019) Influence of rainfall on atmospheric deposition fluxes of $7 \mathrm{Be}$ and $210 \mathrm{~Pb}$ in Mangaluru (Mangalore) at the Southwest Coast of India. Atmos Environ 202:281-295. https:// doi.org/10.1016/j.atmosenv.2019.01.034

Musthafa M, Krishnamoorthy R (2011) Estimation of ${ }^{210} \mathrm{Po}$ and ${ }^{210} \mathrm{~Pb}$ and its dose to human beings due to consumption of marine species of Ennore Creek, South India. Environ Monit Assess 184(10):62536260. https://doi.org/10.1007/s10661-011-2417-8

NandhaKumari P, Selvi A, Sarojini V, Palavesam A (2014) Analysis of radioactivity content in sediment, water and fish collected from Rajakkamangalam Estury of Kanyakumari District in Tamilnadu, India. IOSR J Environ Sci Toxicol Food Technol 8(12):01-03. https://doi.org/10.9790/2402-081210103

Nishikiori T, Suzuki S (2017) Radiocesium decontamination of a riverside in Fukushima, Japan. J Environ Radioact 177:58-64. https:// doi.org/10.1016/j.jenvrad.2017.06.005

Ogata Y (2013) Fallout by the disaster of Fukushima Daiichi nuclear Plant at Nagoya. Radiat Meas 55:96-98. https://doi.org/10.1016/j. radmeas.2013.02.018

Palomares MLD and Pauly D Editors (2019). SeaLifeBase. World Wide Web electronic publication. www.sealifebase.org (12/2019)

Peng A, Liu G, Jiang Z, Liu G, Liu M (2019) Wet depositional fluxes of ${ }^{7} \mathrm{Be}$ and ${ }^{210} \mathrm{~Pb}$ and their influencing factors at two characteristic cities of China. Appl Radiat Isot 147:21-30. https://doi.org/10. 1016/j.apradiso.2019.01.016

Pinnegar JK, Polunin NVC, Badalamenti F (2003) Long-term changes in the trophic level of western Mediterranean fishery and aquaculture landings. Can J Fish Aquat Sci 60(2):222-235

Raja P, Shahul Hameed P (2010) Study on the distribution and bioaccumulation of natural radionuclides, ${ }^{210} \mathrm{Po}$ and ${ }^{210} \mathrm{~Pb}$ in Parangipettai Coast, South East Coast of India. Indian J Mar Sci 39(3):449-455
Ramzaev V, Bøtter-Jensen L, Thomsen K, Andersson K, Murray A (2008) An assessment of cumulative external doses from Chernobyl fallout for a forested area in Russia using the optically stimulated luminescence from quartz inclusions in bricks. J Environ Radioact 99(7):1154-1164. https://doi.org/10.1016/j.jenvrad.2008. 01.014

Savino F, Pugliese M, Quarto M, Adamo P, Loffredo F, De Cicco F, Roca V (2017) Thirty years after Chernobyl: long-term determination of ${ }^{137} \mathrm{Cs}$ effective half-life in the lichen Stereocaulon vesuvianum. J Environ Radioact 172:201-206. https://doi.org/10. 1016/j.jenvrad.2017.03.002

Štrok M, Smodiš B (2011) Levels of ${ }^{210} \mathrm{Po}$ and ${ }^{210} \mathrm{~Pb}$ in fish and molluscs in Slovenia and the related dose assessment to the population. Chemosphere 82(7):970-976. https://doi.org/10.1016/j. chemosphere.2010.10.075

Szefer P, Szefer K, Falandysz J (1990) Uranium and thorium in muscle tissue of fish taken from the southern Baltic. Helgoländer Meeresun 44(1):31-38. https://doi.org/10.1007/BF02365429

TCVN (2008) Vietnam Standard Guideline for Food (in Vietnamese)

Turgay M, Yazici A, Taskin H, Kam E, Karahan G (2015) Assessment of gross $\alpha$ and $\beta$ radioactivity for drinking water in Hatay province, Turkey. Desalin Water Treat 57(11):4960-4965. https://doi.org/10. 1080/19443994.2014.1000384

Van T, Bat L, Nhan D, Quang N, Cam B, Hung L (2018) Estimation of radionuclide concentrations and average annual committed effective dose due to ingestion for the population in the Red River Delta, Vietnam. Environ Manag 63(4):444-454. https://doi.org/10.1007/ s00267-018-1007-8

Vlasova I, Shiryaev A, Ogorodnikov B, Burakov B, Dolgopolova E, Senin R, Averin A, Zubavichus Y, Kalmykov S (2015) Radioactivity distribution in fuel-containing materials (Chernobyl "lava") and aerosols from the Chernobyl "shelter". Radiat Meas 83:20-25. https://doi.org/10.1016/j.radmeas.2015.06.005

WHO (2017) Guidelines for drinking-water quality, 4th edition, incorporating the 1st addendum. World Health Organ 1(7):152-164

Zorer Ö, Öter Ç (2015) Evaluation of gross radioactivity in foodstuffs. Kerntechnik 80(2):174-179. https://doi.org/10.3139/124.110492

Publisher's note Springer Nature remains neutral with regard to jurisdictional claims in published maps and institutional affiliations. 